\title{
PERAN DAN IMPLEMENTASI WAQAF DALAM PENINGKATAN KESEJAHTERAAN MASYARAKAT
}

\author{
Muhamad Nafik Hadi Ryandono \\ Universitas Airlangga Surabaya \\ mubammadnafik@yahoo.com \\ Bashlul Hazami \\ Universitas Airlangga Surabaya \\ bash.hazami@gmail.com
}

\begin{abstract}
This study aims to answer how the role and implementation of the waqf to increase in the public welfare. Research approach is qualitative approach explanatory. Data collection of documentation, interviews and direct observation as well as the strategy is a case study. Techniques of analysis is descriptive narrative analysis techniques and pairing pattern. The key informant was led Laznas $X$ in Surabaya and informants supporters are the recipients of empowerment. The results showed that the three keys to success in the role and implementation waqf empowerment to increase social welfare is; First, the successful establishment of characters that start with a particular prayer coaching five daily prayers. Second, success in spiritual mental financing among others; soul trustworthy, honest, hardworking and profesional. Third, mentoring and monetoring for financing revenue. Money-run Waqf economical and professional management have a greater impact on the improvement of social welfare compared to waqf immovable assets.
\end{abstract}

Keywords: Waqf, Public Welfare, Characters Dan Empowerment

\begin{abstract}
Abstrak
Penelitian ini bertujuan untuk menjawab bagaimana peran dan implementasi waqaf dalam peningkatan kesejabteraan masyarakat. Pendekatan penelitiannya adalah pendekatan kualitatif explanatory. Pengumpulan datanya dengan dokumentasi, wawancara dan pengamatan langsung serta strateginya adalah case study. Teknik analisisnya adalah teknik analisis diskriptif naratif dan penjodohan pola. Informan kuncinya adalah pimpinan Laznas X di Kota Surabaya dan informan pendukungnya yaitu para penerima pemberdayaan. Hasil penelitian adalah tiga kunci sukses peran dan implementasi waqaf dalam pemberdayaan untuk peningkatan kesejabteraan masyarakat adalab; pertama, keberhasilan pembentukan karakter yang dimulai dengan pembianan sholatnya khususnya shalat lima waktu. Kedua, keberhasilan dalam pembianaan mental spiritual antara lain; jiwa amanah, jujur, pekerja keras dan profesioanal. Ketiga, pendampingan dan monetoring selama penerimaan pembiayaan. Waqaf Uang yang dikelola dengan ekonomis dan manajemen yang profesional memiliki dampak lebih terhadap peningkatan kesejabteraan masyarakat dibandingkan dengan waqaf aset tak bergerak.
\end{abstract}

Kata Kunci: Waqaf, Kesejahteraan Masyarakat, Karakter dan Pemberdayaan.

Permalink/DOI: http://dx.doi.org/10.18326/infsl3.v10i1.239-264 


\section{Pendahuluan}

Waqaf adalah salah satu bentuk ibadah untuk mendekatkan diri pada Allah SWT yang berkaitan dengan pembelanjaan harta. Amalan waqaf sangat besar artinya bagi kehidupan sosial ekonomi, kebudayaan, politik, keuangan dan keagamaan. Oleh karena itu, Islam meletakkan amalan waqaf sebagai salah satu macam ibadah yang amat digembirakan (Basyir, 1987: 7). Waqaf merupakan salah satu instrumen dalam Islam untuk mencapai tujuan ekonomi Islam yaitu mewujudkan kehidupan yang sejahtera dunia akhirat. Negara-negara berpenduduk muslim seperti Mesir, Saudi Arabia, Yordania, Turki, Bangladesh, Mesir, Malaysia dan Amerika Serikat, mengembangkan dan menerapkan waqaf sebagai salah instrumen untuk membantu berbagai kegiatan umat dan mengatasi masalah umat seperti kemiskinan (Prihatini, 2005: 131).

Institusi perwaqafan merupakan salah satu aset masyarakat (public good) dari aspek sosial yang perlu mendapat perhatian sebagai penopang hidup dan harga diri umat Islam. Waqaf secara sosial ekonomi memiliki keunggulan dibandingkan zakat, infaq dan sedekah. Zakat yang yang pada umumnya hanya dikeluarkan lalu disalurkan kemudian didistribusikan dan habis wujudnya begitu pula manfaatnya sama halnya dengan sedekah dan infaq. Waqaf yang memiliki prinsip utama yaitu dalam hal pembayaran waqaf, pokok waqaf harus tetap kekal sedangkan yang diberikan hanya manfaatnya, sehingga manfaat waqaf tetap ada selama pokok masih ada sehingga waqaf merupakan modal dalam perjuangan Islam.

Indonesia merupakan negara berpenduduk muslim terbesar di dunia maka memiliki potensi yang dapat dimanfaatkan untuk menerapkan peran waqaf demi menciptakan keadilan sosial untuk muwujudkan kesejahteraan umat dan mengentaskan kemiskinan. Pengelolaan waqaf di Indonesia masih kurang mengarah pada pemberdayaan ekonomi umat dan cenderung hanya untuk kepentingan ibadah maghdah.

Waqaf di Indonesia dalam pengelolaannya mengalami perubahan dan perkembangan signikan setelah pada tahun 2004 lahir Undang-Undang Perwaqafan yaitu UU No. 41 tahun 2004. Hidayati, (2010: 125) berpendapat bahwa lahirnya Undang-undang waqaf 
No. 41 tahun 2004 tersebut merupakan satu kemajuan yang sangat signifikan bagi umat Islam. Pendapat lain dikemukan oleh Usman (2009: 132) yaitu setelah diresmikannya UU No.41 Tahun 2004, kemudian diteruskan dengan dibentuknya Badan Waqaf Indonesia (BWI) sebagai lembaga independen yang secara khusus mengelola dana waqaf dan beroperasi secara nasional. Tugas dari lembaga ini adalah untuk memajukan dan mengembangkan perwaqafan nasional di Indonesia. BWI berkedudukan di ibukota negara dan dapat membentuk perwakilan di provinsi atau kabupaten atau kota sesuai dengan kebutuhan.

Pasca disyahkannya UU No.41 Tahun 2004 Tentang Waqaf merupakan tonggak baru dalam perwaqafan di Indonesia. Waqaf mengalami pergeseran paradigma dari bentuk aset tidak bergerak berkembang dalam aset bergerak, aset berbentuk surat berharga, uang dan aset-aset lainnya. Waqaf uang dan aset keuangan lainnya apabila dikelola secara profesional akan lebih mudah diproduktifkan untuk menggerakan perekonomian dengan tujuan utamanya adalah pemberdayaan dan peningkatkan kesejahteraan masyarakat miskin.

Pendayagunaan dan pengembangan waqaf baik aset bergerak maupun aset tidak bergerak yang ada di Indonesia membutuhkan komitmen bersama antara pemerintah, ulama dan masyarakat serta komponen lain yang relevan. Dan perlu dirumuskan kembali mengenai berbagai hal seperti harta yang diwaqafkan, peruntukkan waqaf dan nazhir serta pengelolaan waqaf secara produktif profesional. Pemerintah telah memberikan perhatian yang sangat besar dalam pemberdayaan waqaf sebagai bagian dalam menggerakan perekonomian masyarakat. Pada sisi lain waqaf adalah alternatif solusi dalam pengembangan dan pemberdayaan ekonomi dalam rangka peningkatkan kesejahteraan masyarakat khususnya masyarakat miskin. Berdasarkan uraian di atas maka rumusan masalah dalam penelitian ini adalah bagaimana peran dan implementasi waqaf dalam mewujudkan serta meningkatkan kesejahteraan masyarakat? 


\section{Waqaf Perspektif Fiqh}

Waqaf secara bahasa berasal dari bahasa Arab waqafa. Asal kata waqafa berarti menahan, berhenti, diam di tempat, atau tetap berdiri. Kata waqafa-yaqifu-waqfan sama artinya dengan habasayahbisu-tahbisan menahan (Al-Khathib, 26). Waqaf dalam bahasa Arab mengandung pengertian menahan, menahan harta untuk diwaqafkan, tidak dipindahmilikkan. Dengan kata lain, waqaf adalah menyerahkan tanah kepada orang-orang miskin untuk ditahan, karena barang milik itu dipegang dan ditahan oleh orang lain, seperti menahan hewan ternak, tanah, dan segala sesuatu (Fauzia, 2003: 176).

Waqaf dalam istilah syara' adalah sejenis pemberian dengan pelaksanaannya dengan cara menahan (pemilikan) kemudian menjadikan manfaatnya berlaku umum. Yang dimaksud kepemilikan adalah menahan barang yang diwaqafkan agar tidak diwariskan, dijual, dihibahkan, didagangkan, digadaikan, maupun disewakan. Sedangkan cara pemanfaatannya adalah menggunakan sesuai dengan kehendak sang pemberi waqaf tanpa imbalan (Ali, 1988: 53-56).

Mundzir Qahaf (1995: 64), berpendapat waqaf adalah memberikan harta atau pokok benda yang produktif terlepas dari campur tangan pribadi, menyalurkan hasil dan manfaatnya secara khusus sesuai dengan tujuan waqaf, baik untuk kepentingan perorangan, masyarakat, agama atau umum. Al-Minawi (1990: 340) mendefinisikan waqaf dengan Menahan harta benda yang dimiliki dan menyalurkan manfaatnya dengan tetap menjaga pokok barang dan keabadiannya yang berasal dari para dermawan atau pihak umum selain dari harta maksiat semata-mata karena ingin mendekatkan diri kepada Allah Subhanahu wa Ta'ala.

Waqaf dalam terminologi Hukum Islam adalah suatu tindakan penahanan dari penggunaan dan penyerahan aset di mana seseorang dapat memanfaatkan atau menggunakan hasilnya untuk tujuan amal, sepanjang barang tersebut masih ada (Mannan, 2005: 29). Sumber lain menyatakan bahwa waqaf berarti menahan tindakan hukum. Persoalan waqaf adalah persoalan pemindahan hak milik yang dimanfaatkan untuk kepentingan umum (Dahlan, 2003: 190). 
Waqaf menurut perundang-undangan di Indonesia adalah; (1) Peraturan Pemerintah Nomor 28 tahun 1977, waqaf adalah perbuatan hukum seseorang atau badan hukum yang memisahkan sebagian dari harta kekayaannya yang berupa tanah milik dan kelembagaannya untuk selamalamanya untuk kepentingan atau keperluan umat lainnya sesuai ajaran Islam; (2) Kompilasi Hukum Islam (KHI), waqaf adalah perbuatan hukum seseorang atau kelompok orang atau badan hukum yang memisahkan sebagian dari benda miliknya dan kelembagaannya untuk selama-lamanya guna kepentingan ibadah atau keperluan umum lainnya sesuai ajaran Islam; (3) Undang-Undang Waqaf Nomor 41 Tahun 2004 dinyatakan bahwa waqaf adalah perbuatan hukum wakif untuk memisahkan dan/atau menyerahkan sebagian harta benda miliknya untuk dimanfaatkan selamanya atau untuk jangka waktu tertentu sesuai dengan kepentingannya guna keperluan ibadah dan/ atau kesejahteraan umum menurut syari'ah; (4) Peraturan Waqaf Indonesia Nomor 4 Tahun 2010 tentang Pedoman Pengelolaan dan Pengembangan Harta Benda Waqaf mendefinisikan waqaf adalah perbuatan hukum wakif untuk memisahkan dan/atau menyerahkan sebagian harta benda miliknya untuk dimanfaatkan selamanya atau untuk jangka waktu tertentu sesuai dengan kepentingannya guna keperluan ibadah dan/atau kesejahteraan umum menurut syariah.

Para fuqaha berbeda pendapat dalam mendefinisikan waqaf (Al-Kabisi, 2004: 87-88) antara lain, a) Abu Hanifah yang diriwayatkan oleh Wahbah Az-Zuhaily, Waqaf adalah penghentian benda tidak bergerak dari pemilikan waqif secara hukum dan penyedekahan manfaatnya untuk kepentingan umum. b) Abu Yusuf dan Muhammad bin al-Hasan, golongan Syafi'iyyah dan golongan Hanabilah, Waqaf adalah menahan harta yang memungkinkan diambil manfaatnya, tetapi bukan untuk dirinya, dibelanjakan waqif untuk mendekatkan diri kepada Allah SWT. Dengan diwaqafkan itu, harta keluar dari pemilikan waqif dan harta tersebut secara hukum milik Allah SWT. Bagi waqif terhalang untuk memanfaatkannya dan wajib mendermakan hasilnya untuk tujuan kebaikan. c) Golongan Malikiyah, Waqaf mempunyai arti bahwa pemilik harta memberikan manfaat harta yang dimiliki bagi mustahiq. Menurut mereka harta tersebut dapat berupa benda yang disewa kemudian hasilnya 
diwaqafkan. Kelebihan dari pendapat Malikiyah ini, yakni orang yang berwaqaf tidak harus menunggu yang bersangkutan memiliki tanah (benda yang diwaqafkan) akan tetapi cukup menyewa benda, yang akan diwaqafkan adalah hasilnya. Hal ini banyak manfaatnya terutama untuk memelihara harta waqaf yang ada. Di sisi lain pendapat ini akan menyebabkan lemahnya lembaga waqaf dan tidak sesuai dengan pendapat Jumhur Ulama yang mensyaratkan bahwa benda yang diwaqafkan itu harus tetap zatnya dan dapat dimanfaatkan terus menerus.

Dalam Al-Qur'an terdapat beberapa ayat yang menganjurkan untuk menunaikan waqaf antara lain surat Ali Imran:92, Al baqarah: 261 dan Al-Baqarah: 267.

"Kamu sekali-kali tidak sampai kepada kebajikan (yang sempurna), sebelum kamu menafkabkan sebahagian barta yang kamu cintai. Dan apa saja yang kamu nafkabkan, maka sesunggubnya Allah mengetahuinya. (QS, 3 Al-Imran: 92).

"Perumpamaan (nafkah yang dikeluarkan oleb) orangorang yang menafkahkan hartanya di jalan Allab adalab serupa dengan sebutir benih yang menumbubkan tujub bulir, pada tiaptiap bulir seratus biji. Allab melipat gandakan (ganjaran) bagi siapa yang dia kehendaki, dan Allah Maha luas (karunia-Nya) lagi Maha Mengetabui". (QS 2, Al-Baqarah: 261).

"Hai orang-orang yang beriman, nafkahkanlab (di jalan Allab) sebagian dari hasil usahamu yang baik-baik dan sebagian dari apa yang Kami keluarkan dari bumi untuk kamu. Dan janganlab kamu memilib yang buruk-buruk lalu kamu nafkabkan daripadanya, padahal kamu sendiri tidak mau mengambilnya melainkan dengan memicingkan mata terbadapnya. Dan ketahuilah, bahwa Allah Maha Kaya lagi Maha Terpuji". (QS 2, Al Baqarah:267)

Selain Al-Qur'an yang dijadikan sebagai rujukan dalam mengamalkan waqaf, terdapat pula hadits yang dijadikan dasar mengamalkan waqaf,

Dari Abu Hurairah ra. Sesunggubnya Rasulullab Saw bersabda: Apabila manusia mati, maka terputuslahamalannya, 
kecuali tiga perkara: sedekah jariyah, ilmu yang bermanfaat dan anak saleb yang mendoakannya. (HR. Muslim).

Hadits Nabi yang secara tegas menyinggung dianjurkannya ibadah waqaf, yaitu perintah Nabi kepada Umar untuk mewaqafkan tanahnya yang ada di Khaibar:

"Dari Ibnu Umar ra. Berkata, bahwa sahabat Umar Ra. Memperoleh sebidang tanah di Khaibar kemudian menghadap kepada Rasulullah untukm memohon petunjuk Umar berkata: Ya Rasulullah, saya mendapatkan sebidang tanah di Khaibar, saya belum pernah mendapatkan harta sebaik itu, maka apakah engkau perintabkan kepadaku? Rasulullab menjawab: Bila kamu suka, kamu tahan (pokoknya) ntanab itu, dan kamu sedekabkan (hasilnya). Kemudian Umar menyedekabkannya kepada orangorang fakir, kaum kerabat, budak belian, sabilillah, ibnu sabil dan tamu. Dan tidak mengapa atau tidak dilarang bagi yang menguasai tanah waqaf itu (pengurusnya) makan dari hasilnya dengan cara yang baik (sepantasnya) atau makan dengan tidak bermaksud menumpuk harta". (HR. Muslim) (Al-Bukhari, 1981: 185).

Waqaf berdasarkan tujuannya, menjadi beberapa klasifikasi yaitu waktunya, dan penggunaannya (Qahaf, 2005: 161). Waqaf berdasarkan tujuannya terdiri dari : a) Waqaf sosial untuk kebaikan masyarakat (khairy), yaitu apabila tujuan waqafnya untuk kepentingan umum. b) Waqaf keluarga (dhurri), yaitu apabila tujuan waqaf untuk memberi manfaat kepada waqif, keluarganya dan keturunannya. c) Waqaf gabungan (mushtarak), yaitu apabila tujuan waqafnya untuk umum dan keluarga secara bersamaan.

Berdasarkan batasan waktunya, waqaf terbagi menjadi 2 macam: a) Waqaf abadi, yaitu waqaf berbentuk barang yang bersifat abadi seperti tanah dan bangunan atau barang bergerak yang ditentukan oleh wakif sebagai waqaf abadi. b) Waqaf sementara, yaitu apabila barang yang diwaqafkan berupa barang yang mudah rusak ketika dipergunakan tanpa memberi syarat untuk mengganti bagian yang rusak.

Berdasarkan penggunaannya, waqaf terbagi menjadi dua macam: a) Waqaf langsung, yaitu waqaf yang pokok barangnya 
digunakan untuk mencapai tujuannya seperti masjid untuk shalat, sekolah untuk kegiatan belajar mengajar dan sebagainya. b) Waqaf produktif, waqaf yang pokok barangnya digunakan untuk kegiatan produksi dan hasilnya diberikan sesuai dengan tujuan waqaf.

\section{Perkembangan Pengelolaan Waqaf di Indonesia}

Waqaf di Indonesia dikenal seiring dengan perkembangan dakwah Islam di Nusantara. Ajaran waqaf ini terus berkembang, baik pada masa dakwah pra kolonial, masa kolonial, maupun pasca kolonial pada masa Indonesia merdeka. Masa pemerintahan kolonial perkembangan organisasi keagamaan, sekolah, madrasah, pondok pesantren, masjid, semuanya merupakan swadaya dan berdiri di atas tanah waqaf. Namun, perkembangan waqaf di kemudian hari tak mengalami perubahan yang berarti. Kegiatan waqaf dilakukan terbatas untuk kegiatan keagamaan, seperti pembangunan masjid, mushalla, langgar, madrasah, perkuburan, sehingga kegiatan waqaf di Indonesia kurang bermanfaat secara ekonomis bagi rakyat banyak (Hasan, 2009).

Pengelolaan waqaf mulai diperhatikan oleh pemerintah dengan ditandai adanya peraturan perwaqafan yakni PP No. 28 tahun 1977 tentang Perwaqafan Tanah Milik. Akan tetapi PP ini hanya mengatur waqaf pertanahan saja. tidak jauh beda dengan model waqaf pada periode awal. Seiring dengan adanya Peradilan Agama yang dibentuk berdasarkan Undang-Undang No. 7 Tahun 1989 tentang Peradilan Agama, dibutuhkan suatu pedoman untuk menyelesaikan sengketa tentang waqaf yang dirasa oleh hakim Pengadilan Agama masih kurang apabila hanya mendasarkan ketentuan dari PP No. 28 Tahun 1977. Untuk itu ditetapkanlah Instruksi Presiden No. 1 Tahun 1991 Tentang Kompilasi Hukum Islam (Kementerian Agama, 2013: 29-30).

Stagnasi perkembangan waqaf di Indonesia mulai mengalami dinamisasi ketika pada tahun 2001, beberapa praktisi ekonomi Islam mulai mengusung paradigma baru ke tengah masyarakat mengenai konsep baru pengelolaan waqaf tunai untuk peningkatan kesejahteraan umat. Konsep tersebut ternyata menarik dan mampu memberikan energi untuk menggerakkan kemandegan 
perkembangan waqaf. Kemudian pada tahun 2002, Majelis Ulama Indonesia (MUI) menyambut konsep tersebut dengan mengeluarkan fatwa yang membolehkan waqaf uang (waqf al-nuqud). Pada masa reformasi, pengelolaan waqaf semakin berkembang dengan terbitnya undang-undang yang khusus mengatur waqaf. Pada masa ini, landasan hukum pengelolaan waqaf menjadi lebih tinggi karena sudah dalam bentuk undang-undang.

Peraturan perwaqafan tersebut yaitu Undang-Undang Nomor 41 Tahun 2004 Tentang Waqaf dan Peraturan Pemerintah Nomor 42 Tahun 2006 Tentang Pelaksanaan Undang-Undang Nomor 41 Tahun 2004 Tentang Waqaf. Hadirnya Undang-Undang No. 41 Tahun 2004 tentang waqaf memberikan pijakan hukum yang pasti, kepercayaan publik, serta perlindungan terhadap aset waqaf. Pengesahan undang-undang ini merupakan langkah strategis untuk meningkatkan kesejahteraan umum, meningkatkan peran waqaf, tidak hanya sebagai pranata keagamaan saja, tetapi juga memiliki kekuatan ekonomi yang potensial untuk memajukan kesejahteraan umum. Di samping itu, dengan disahkannya undang-undang ini, objek waqaf lebih luas cakupannya tidak hanya sebatas benda tidak bergerak saja, tapi juga meliputi benda bergerak seperti uang, logam mulia, surat berharga, hak sewa dan sebagainya.

Lahirnya Undang-Undang Nomor 41 Tahun 2004 menjadi titik sejarah dalam pengelolaan waqaf di Indonesia. Dengan diaturnya waqaf dalam bentuk undang-undang, maka sektor waqaf dapat menjadi solusi alternatif peningkatan kesejahteraan sosial ekonomi masyarakat. Pengelolaan dan pengembangan harta waqaf bisa dilakukan secara produktif.

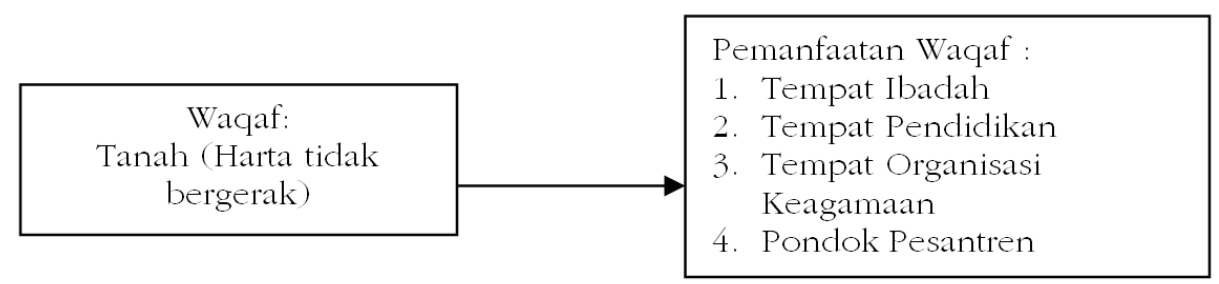

\section{Gambar 1 \\ Pengelolaan Waqaf Sebelum Terbit UU Waqaf}

Sumber: Darwanto.2012. 
Berdasarkan gambar 1, sebelum masa reformasi, waqaf pada umumnya dalam bentuk tanah (harta tidak bergerak) dan sulit untuk dikembangkan. Pendayagunaan waqaf untuk keperluan lain masih terkendala dengan terbatasnya pemahaman hukum pengelolaan waqaf para nazhir (pengelola waqaf). Berdasarkan UU No. 41 Tahun 2004, waqaf mengalami perkembangan ke arah peningkatan kesejahteraan sosial ekonomi masyarakat.

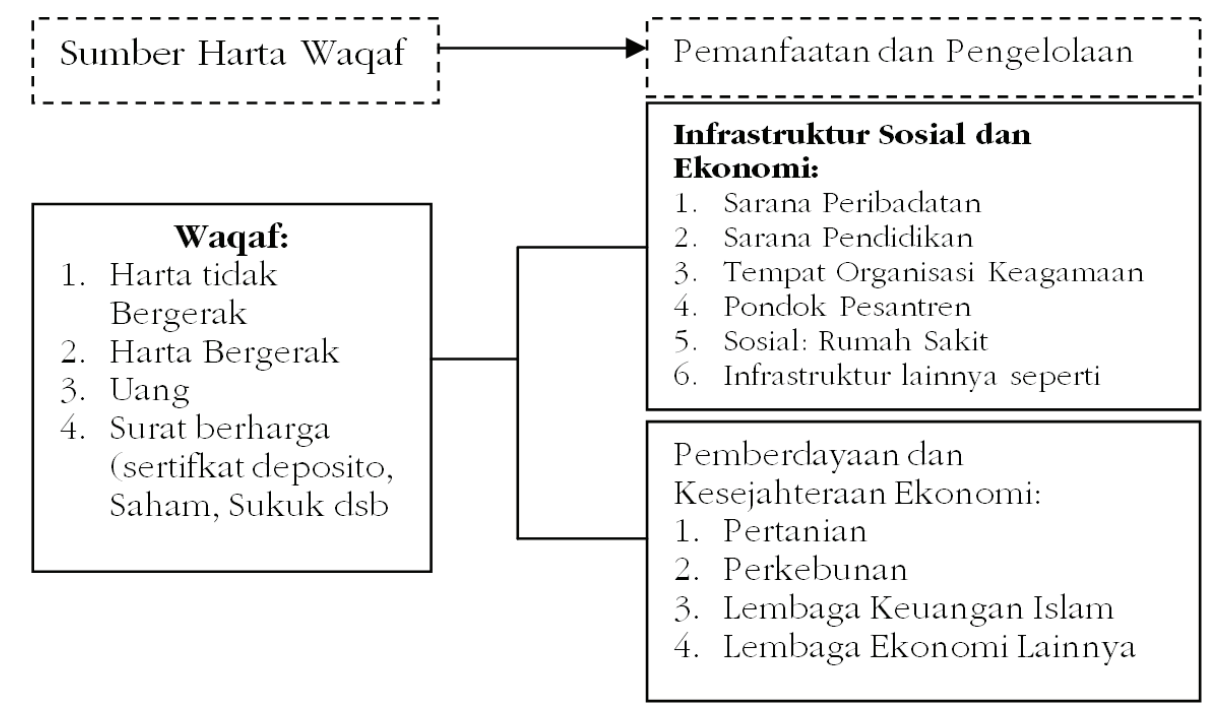

\section{Gambar 2. \\ Model Pengelolaan Waqaf Pasca UU No. 41 Tahun 2004 tentang Waqaf}

Gambar 2 menunjukkan bahwa proses pengelolaan waqaf berkembang, khususnya tentang harta waqaf dan pemanfaatan waqaf. Perkembangan harta waqaf memungkingkan dapat dikembangkan lebih maksimal dan produktif yaitu tidak hanya pengembangan dalam bentuk infrastruktur secara fisik yang berupa public good tetapi juga dikembangkan dalam bentuk infrastruktur untuk pemberdayaan ekonomi demi peningkatan kesejahteraan masyarakat.

Waqaf uang merupakan pengembangan dasar dari konsep waqaf produktif. Waqaf uang mempunyai peluang bagi terciptanya investasi umat dalam aspek keagamaan, pendidikan, dan pelayanan 
social masyarakat. Waqaf di negara-negara muslim lain tidak hanya dikelola dalam bentuk konsumtif tetapi juga dalam bentuk produktif. Waqaf dikembangkan juga dalam bentuk produktif usaha pertanian, perkebunan, uang, saham, real estate dan lain-lain. Pengelola waqaf yang demikian diharapkan hasilnya benar-benar mampu mewujudkan kesejahteraan umat dan tujuan syariah (maqashid syariab) secara umum. Pada perkembangan ini pengelolaan dan pemnafaatan waqaf mulai dikategorikan dalam dua kategori yaitu waqaf produktif dan waqaf konsumtif, seperti bagan dibawah ini:

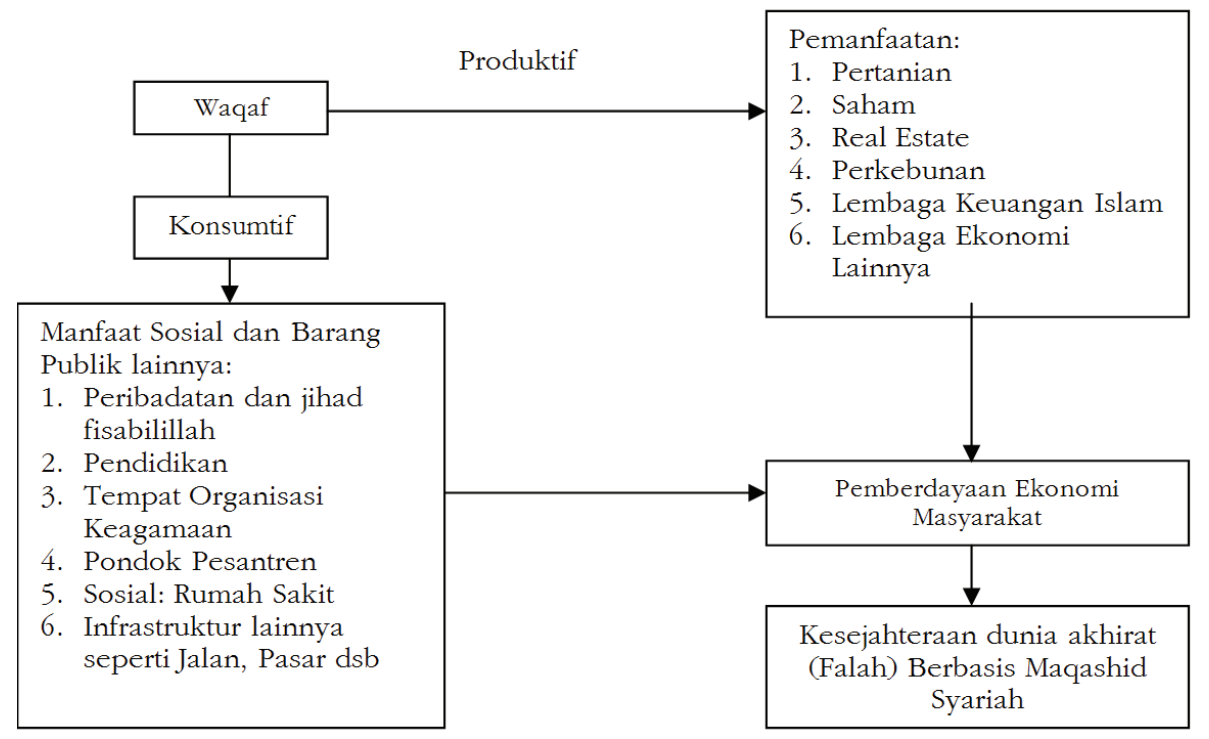

\section{Gambar 3. Model Pengelolaan Waqaf Berbasis Maqashid Syariab}

Walaupun pada realitasnya menurut Nasution (2006:38) pengelolaan waqaf di Indonesia masih menghadapi permasalahan, antara lain pengelolaan lembaga waqaf, dan masyarakat masih tergiur dengan sistem ekonomi non syari'ah, belum adanya undangundang waqaf yang komprehensif-integral, masalah yang berkaitan dengan fikih waqaf . Perwaqafan di Indonesia membutuhkan sebuah managemen yang modern dan profesional untuk mengelola waqaf menjadi lebih produktif agar tercapai tujuan pengelolaan waqaf baik secara hukum Islam maupun sosial ekonomi. 
Waqaf Sebagai Instrumen Pemberdayaan dan Transformasi Kesejahtreraan

Fakir dan miskin sebagai asnaf(penerima zakat) memerlukan perlakuan khusus agar besok harinya bisa memenuhi kebutuhan pokoknya secara mandiri tanpa menerima zakat atau shadaqah kembali. Oleh karena itu harus diberdayakan dengan tujuan akan mentransformasi dirinya menjadi lebih sejahtera dan semakin mampu menghidupi dirinya sendiri dan atau bahkan suatu saat nanti akan mampu mentransformasi dirinya dari penerima zakat (mustabiq) menjadi penunai zakat (muzakki). Karena tujuan sebenarnya dari pengelolaan zakat oleh lembaga zakat (amil) adalah melakukan pemberdayaan para mustahiq agar mampu memenuhi kebutuhan hidupnya dan masa akan datang akan bertransformasi menjadi muzakki.

Lembaga zakat dalam memberdayakan para fakir dan miskin tersebut juga dapat mengumpulkan waqaf baik berwujud barang atau aset dan berwujud uang. Waqaf uang yang terkumpul dapat digunakan sebagai modal untuk mendirikan lembaga keuangan yang tujuan utamanya untuk menyalurkan dananya kepada para fakir dan miskin. Penyaluran dana tersebut dengan menggunakan akad transksi bisnis yang dibenarkan secara fiqh antara laib sistem bagi hasil (mudharabah dan Musyarakah), jual beli (murabahah, salam dan Istishna'), sewa (ijarah) dan pinjaman murni (Qard) dan sebaiknya jangan menggunakan akad tabarru (kebaikan) karena dana waqaf uang harus berkembang dan tumbuh. Hasil pengelolaan waqaf tersebut kemudian untuk memperbesar modal lembaga keuangannya dan untuk membiaya perjuangan dalam hal ini untuk lebih banyak yang bisa diberdayakan secara ekonomi.

Fakiradalah suatu kondisi seseorang tidak memliki pekerjaan atau tidak mampu bekerja otomatis tidak memliki mendapatan untuk memenuhi kebutuhan hidupnya baik diri sendiri maupun keluarganya. Pemenuhan kebutuhan hidup golongan fakir sepenuhnya tergantung pada pihak lain. Miskin adalah suatu kondisi seseorang yang memiliki pekerjaan (pendapatan) atau mampu bekerja tetapi pendapatannya tersebut tidak cukup untuk memenuhi kebutuhan hidup baik diri sendiri maupun keluarganya. 
Dengan demikian kondisi miskin ini lebih baik dari fakir maka dalam mengelola zakat yang dprioritaskan adalah fakir. Proses transformasi fakir dan miskin menjadi muzakki secara mekanistik yaitu dengan cara bagaimana mereka bisa bekerja dan atau meningkatkan pendapatannya dari waktu ke waktu, seperti pada Gambar 4.

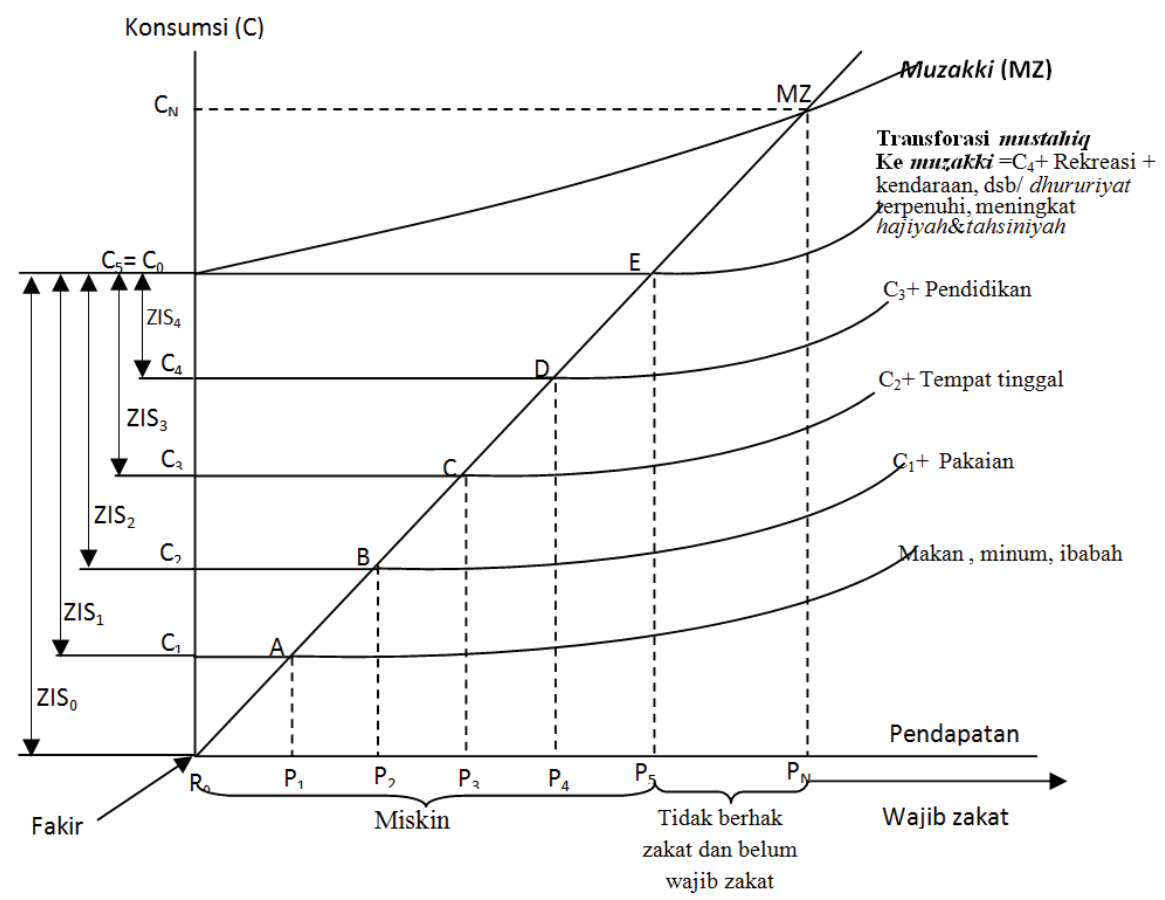

\section{Gambar 4}

\section{Manhard Model: Pemberdayaan dan Transformasi Ekonomi}

Sumber: Muhamad Nafik H.R. 2012.

Keterangan :

$\mathrm{P}_{0}-\mathrm{P}_{5} \quad$ : Tingkat Pendapatan fakir dan miskin

$\mathrm{P}_{\mathrm{N}} \quad$ : Tingkat Pendapatan yang telah wajib berzakat (muzakki)

Co : Tingkat Konsumsi Otonom suatu Keluarga

$\mathrm{C}_{1}-\mathrm{C}_{4} \quad$ : Tingkat konsumsi riil suatu keluarga mustabiq

$\mathrm{ZIS}_{0}-\mathrm{ZIS}_{4} \quad$ : Zakat Infaq dan Shadaqah

$\mathrm{C}_{\mathrm{N}} \quad$ : Tingkat konsumsi muzakki 
Titik koordinat pada titik $0\left(\mathrm{P}_{0} ; \mathrm{C}_{0}\right)$ menunjukkan bahwa kelompok keluarga atau individu yang tidak memiliki pendapatan tetapi akan tetap berkonsumsi sebesar $\mathrm{C}_{0}$. Pada titik nol ini seseorang tidak memiliki pendapatan, dikarenakan tidak bekerja atau tidak mampu lagi bekerja karena kondisi fisik maupun jiwanya yang tidak memungkinkan bekerja, sehingga semua kebutuhan hidupnya menggantungkan pada pemberian pihak lain atau kebutuhan hidupnya akan bersumber pada Zakat, Infaq dan Shadaqah sebesar $\mathrm{ZIS}_{0} \mathrm{ZIS}_{0}$ dapat bersumber dari keluarga yang lain atau dari lembaga zakat. Golongan masyarakat ini adalah kelompok yang dikategorikan dalam kelompok atau golongan (asnaf) fakir. Kelompok ini jika dirinya masih mampu bekerja maka harus diberdayakan oleh muzakki dan atau lembaga zakat agar dapat bekerja sehingga dapat berubah (bertransformasi) dari tidak berpendapatan $\left(\mathrm{P}_{0}\right)$ berubah menjadi berpendapatan $\left(\mathrm{P}_{1}, \mathrm{P}_{2}, \mathrm{P}_{3}, \mathrm{P}_{4}\right.$ dan $\left.\mathrm{P}_{5}\right)$ atau meningkat menjadi golongan miskin atau bahkan pada suatu saat nanti akan berpendapatan pada tingkat $\mathrm{P}_{\mathrm{N}}$ atau bertransformasi menjadi muzakki. Pada titik koordinat A, B, C, D dan E adalah kelompok yang masuk kategori miskin. Pada titik koordinat $\mathrm{E}$ samapai titik MZ merupakan titik koordinat seseorang atau keluarga yang telah mangalami proses bertransisi dari mustahiq menjadi muzakki atau bertransformasi dari mustahiq menjadi muzakki. Pada kondisi proses transisi ini maka golongan berpendapatan ini sudah tidak lagi berhak menerima zakat tetapi belum wajib berzakat.

Titik A menunjukkan kelompok yang memiliki pendapatan sebesar $\mathrm{P}_{1}$ dan semuanya habis untuk memenuhi kebutuhannya yang berupa makan, minum dan ibadah sebesar $\mathrm{C}_{1}$ tetapi pendapatannya ini masih belum mampu memenuhi kebutuhan pokoknya atau primer yaitu sebesar $\mathrm{C}_{0}$. Oleh karena itu konsumsi pokoknya masih mengalami kekurangan sebesar $\mathrm{C}_{0}-\mathrm{C}_{1}$ atau karena $\mathrm{P}_{1}$ masih lebih kecil dari $\mathrm{C}_{0}$. Kekurangan konsumsi tersebut dapat ditutup dari penerimaannya dari lembaga zakat sebesar ZIS $_{1}$.

Pada titik koordinat $\mathrm{B}$, kelompok pendapatan ini pendapatanya telah meningkat dari $\mathrm{P}_{1}$ menjadi $\mathrm{P}_{2}$. Tetapi pendapatan ini belum mampu menutup kebutuhan normalnya $\left(\mathrm{C}_{0}\right)$ atau masih mengalami kekurangan pendapatan untuk memenuhi kebutuhannya sebesar $\mathrm{C}_{0}-\mathrm{C}_{2}$ atau karena $\mathrm{P}_{2}$ masih lebih kecil dari $\mathrm{C}_{0}$. Dengan demikian 
kelompok pendapatan ini masih masuk kategori kelompok miskin dan berhak menerima zakat karena pendapatanya belum mampu menutup konsumsi (kebutuhan) pokoknya $\left(\mathrm{C}_{0}\right)$ dalam kehidupannya atau $\mathrm{P}_{2}$ lebih kecil dari $\mathrm{C}_{0}$. Kelompok in akan menutup konsumsinya dari lembaga zakat sebesar ZIS $_{2}$.

Pada titik koordinat C, kelompok ini pendapatanya telah meningkat dari $\mathrm{P}_{2}$ menjadi $\mathrm{P}_{3}$, tetapi pendapatan ini belum mampu menutup kebutuhan normalnya $\left(\mathrm{C}_{0}\right)$ atau masih mengalami kekurangan pendapatan untuk memenuhi kebutuhannya sebesar $\mathrm{C}_{0}-\mathrm{C}_{3}$ atau karena $\mathrm{P}_{3}$ masih lebih kecil dari $\mathrm{C}_{0}$. Dengan demikian kelompok pendapatan ini masih masuk kategori kelompok miskin dan berhak menerima zakat karena pendapatanya belum mampu menutup konsumsi (kebutuhan) normal $\left(\mathrm{C}_{0}\right)$ dalam kehidupannya atau $\mathrm{P}_{3}$ lebih kecil dari $\mathrm{C}_{0}$. Kelompok in akan menutup konsumsinya dari lembaga zakat sebesar ZIS $_{3}$.

Pada titik koordinat $\mathrm{D}$, kelompok ini pendapatanya telah meningkat dari $\mathrm{P}_{3}$ menjadi $\mathrm{P}_{4}$. Tetapi pendapatan ini belum mampu menutup kebutuhan normalnya $\left(\mathrm{C}_{0}\right)$ atau masih mengalami kekurangan pendapatan untuk memenuhi kebutuhannya sebesar $\mathrm{C}_{0}-\mathrm{C}_{4}$ atau karena $\mathrm{P}_{4}$ masih lebih kecil dari $\mathrm{C}_{0}$. Dengan demikian kelompok pendapatan ini masih masuk kategori kelompok miskin dan berhak menerima zakat karena pendapatanya belum mampu menutup konsumsi (kebutuhan) pokok $\left(\mathrm{C}_{0}\right)$ dalam kehidupannya atau $\mathrm{P}_{4}$ lebih kecil dari $\mathrm{C}_{0}$. Kelompok in akan menutup konsumsinya dari lembaga zakat sebesar $\mathrm{ZIS}_{4}$.

Pada titik E, kelompok ini pendapatanya telah meningkat dari $\mathrm{P}_{4}$ menjadi $\mathrm{P}_{5}$ dan merupakan kelompok yang mengalami transisi dari menerima zakat menjadi yang tidak berhak menerima zakat tetapi belum wajib zakat. Kelompok pendatapan pada koordinat titik (golongan) $\mathrm{E}$ ini yang memiliki tingkat pendapatan sebesar $\mathrm{P}_{5}$ memiliki kemampuan riil untuk memenuhi kebutuhannya pokoknya yaitu sebesar $\mathrm{C}_{0}$. Kemampuan pemenuhan kebutuham ini telah berada pada kemampuan pemenuhan kebutuhan pokoknya $\left(\mathrm{C}_{0}\right)$ atau pendapatan sebesar $\mathrm{P}_{5}$ telah cukup untuk memenuhi semua kebutuhan pokonya yaitu sebesar $\mathrm{C}_{0}$. Apabila pendapatan kelompok ini meningkat lagi menjadi $\mathrm{P}_{\mathrm{N}}$ dengan konsumsi pokoknya tetap 
sebesar $\mathrm{C}_{0}$ dan sisa pendapatannya mencapai nisab maka kelopmpok ini telah bertransformsi menjadi kelompok muzakki yaitu pada titik MZ. Mengapa menjadi muzakki?. Karena pada titik MZ ini adalah kelompok pendapatan yang memiliki pendapatan sebesar $\mathrm{P}_{\mathrm{N}}$ dengan kemampuan konsumsi riilnya sebesar $\mathrm{C}_{\mathrm{N}}$ dan kebutuhan normalnya hanya sebesar $C_{0}$ sehingga memiliki sisa pendapatan sebesar $C_{N}-$ $\mathrm{C}_{0}$ atau $\mathrm{P}_{\mathrm{N}}-\mathrm{C}_{0}$. Karena sisa pendapatan ini telah mencapai nisab maka wajib menuaikan zakat. Karena apabila sisa pendapatannya masih dibawah nisab maka kelompok pendapatan ini masih masuk dalam kategori yang belum wajib zakat walaupun memang tidak berhak lagi menerima zakat. Dasar yang dapat digunakan dalam perhitungan nisab zakat adalah harta atau pendapatan setelah dikurangi pengeluaran pokok bagi muzakki dan keluarga yang menjadi tanggungannya adalah surat Al baqarah ayat 219 berikut ini:

"Mereka bertanya kepadamu tentang khamar dan judi. Katakanlah: "Pada keduanya itu terdapat dosa besar dan beberapa manfa at bagi manusia, tetapi dosa keduanya lebih besar dari manfa atnya". Dan mereka bertanya kepadamu apa yang mereka nafkabkan. Katakanlab: "Yang lebih dari keperluan." Demikianlah Allab menerangkan ayat-ayat-Nya kepadamu supaya kamu berfikir," (QS 2, Al Baqarah:219)

Lembaga zakat atau pengelola waqaf memiliki tanggungjawab dalam mempercepat proses transformasi masyarakat fakir dan miskin menjadi sejahtera, dari mustahiq menjadi muzakki.

\section{Metode Penelitian}

Penelitian ini menggunakan pendekatan kualitatif dengan jenis penelitian explanatory. Pengumpulan datanya dari dokumentasi, wawancara dan pengamatan langsung dan strateginya menggunakan studi kasus. Teknik analisis dalam studi kasus yaitu diskriptif naratif yang diperkuat dengan teknik penjodohan pola. Obyek penelitian adalah lembaga zakat x yang juga nazhir berlokasi di Kota Surabaya. Data utama studi kasus ini bersumber dari key informan yaitu pimpinan lembaga zakat. Selanjutnya dilakukan triangulasi data 
kepada penerima pemberdayaan sebagai proses akurasi data dan juga dengan tujuan untuk memotret pemberdayaan ekonominya.

\section{Analisis}

Fomulasi Peran Waqaf Dalam Mewujudkan Kesejabteraan Masyarakat

Pengelolaan waqaf uang menurut key informan untuk pemberdayaan ekonomi dan peningkatan kesejahteraan masyarakat miskin hendaknya disesuaikan dengan potensi masyarakat lingkungannya. Pengelolaan waqaf juga harus tetap memperhatikan kebutuhan praktis masyarakat yang akan diberdayakan dan para penerima peruntukan waqaf (mauquf'alaib).

Waqaf untuk kegiatan pemberdayaan ekonomi dengan tujuan peningkatan kesejahteraan ini maka aktivitas utama dan yang pertama adalah capacity building, tujuannya adalah pembangunan dan pembentukan karakater keimanan agar mereka berdaya lebih dulu secara mental spiritualnya. Keberhasilan pembentukan karakter keimanan dan perilaku yang Islami merupakan kunci sukses keberhasilan pemberdayaan. Mental spiritual yang baik akan membuat seseorang memiliki spirit untuk maju dan keluar dari permasalahan kesejahteraan. Apabila pembangunan dan pembentukan mental spritual telah berhasil maka tahap selanjutnya adalah capacity building sesuai dengan kebutuhan dan potensi masyarakat yaitu aspek membangun kemandirian ekonomi antara lain enterpreneurship, keahlian kerja dan kapasitas lain sesuai dengan kebutuhannya saat melakukan aktivitas ekonominya.

Capacity building tersebut akan lebih efektif apabila lembaga pengelola waqaf menyatu dengan lembaga amil zakat. Tahap selanjutnya, membentuk sistem dan lembaga pendidikan sesuai dengan kebutuhan pemberdayaan dan level edukasi yang akan diberikan. Pembangunan dan operasional lembaga pendidikan itu bisa dibiayai dengan dana Zakat, Infaq dan Shadaqah (ZIS) atau dana waqaf uang. Waqaf uang dapat digunakan sebagai modal pendirian lembaga ekonomi dan keuangan. yang berbasis syariah sebagai sarana dakwah berekonomi Islam seperti Koperasi Jasa Keuangan Syariah (KJKS) atau yang lebih dikenal Baitul wat Tamwil (BMT). BMT akan menggerakan 
aktivitas sektor riil dan memberikan modal kepada masyarakat yang diberdayakan dan hasil pengelolaan lembaga ekonomi dapat digunakan untuk biaya operasional dan gaji para karyawan lembaga zakat dan waqaf. Dengan demikian biaya-biaya tersebut tidak mengambil dari porsi dana Ziswaf (Zakat, Infaq, Shadaqah dan Waqaf) sehingga dana yang terkumpul akan lebih maksimal dan berdaya guna. BMT yang dibentuk memiliki fungsi melatih, mendampingi dan mengembangkan usaha nasabahnya jadi tidak sekedar memberikan pembiayaan dan menunggu pengembalian dananya semata seperti lemaga keuangan konvensional selama ini. Pemberdayaan akan lebih efektif dan efisien apabila mereka yang memungkinkan di boarding (mondok) harus di boarding layaknya di pesantren dan yang tidak mungkin boarding, diberikan pembinaan secara rutin dan kontinu di lembaga pendidikan yang didirikan. Oleh karena itu lembaga zakatnya mendirikan pesantren enterpreneur hafidz Qur'an.

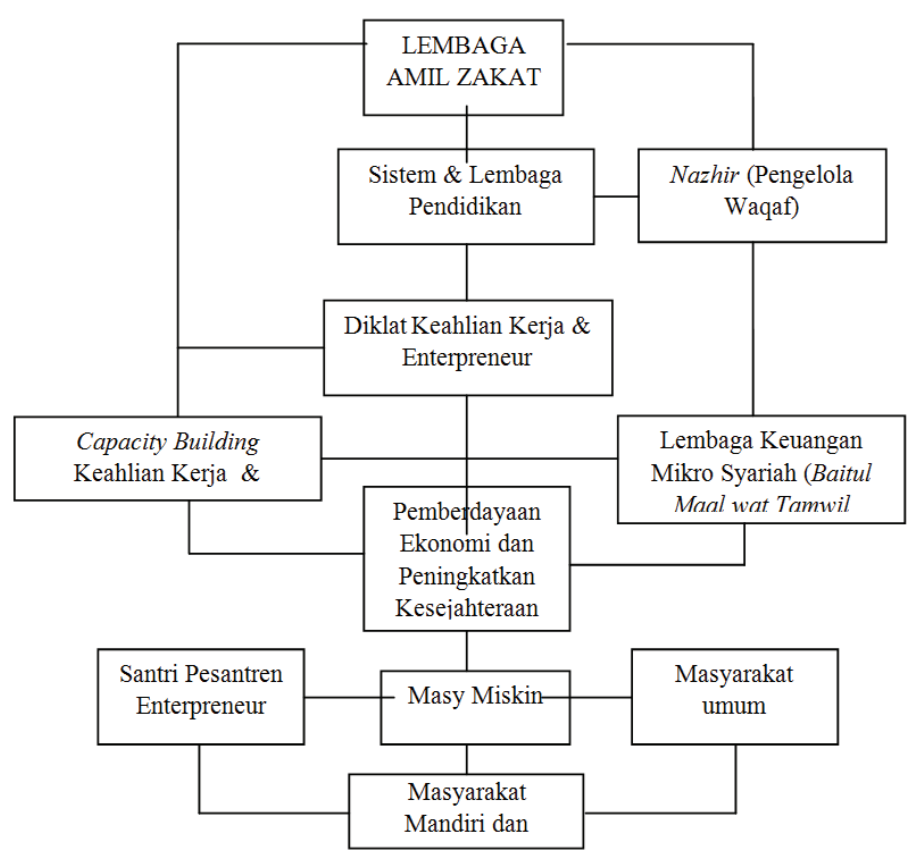

\section{Gambar 5 \\ Sistem Pemberdayaan dan Peningkatan Kesejahteraan Lembaga ZISWAF}

Sumber: Formulasi Hasil Wawancara Key Informan 
Fungsi lembaga pendidikan lainya adalah sebagai wahana dan sarana proses pembinaan bagi para peserta pemberdayaan untuk dididik dalam mendirikan, pengelola, pengembangan usaha secara mandiri dan belajar bekerja secara riil dengan dukungan potensi lembaga Ziswaf, manajemen serta teknologi baik yang telah ada maupun dengan model kemitraan dengan lembaga lain. Tujuan utamanya adalah penyediaan fasilitas untuk pedidikan dan latihan pengembangan usaha, serta untuk meningkatkan maupun mengembangkan kegiatan usaha dan produk baik untuk santri pesantren enterpreneur hafidz Qur'an maupun masyarakat umum sehingga lebih berdaya ekonominya. Ada proses tahapan dan aktivitas pemberdayaan ekonomi masyarakat miskin pada Gambar 6.

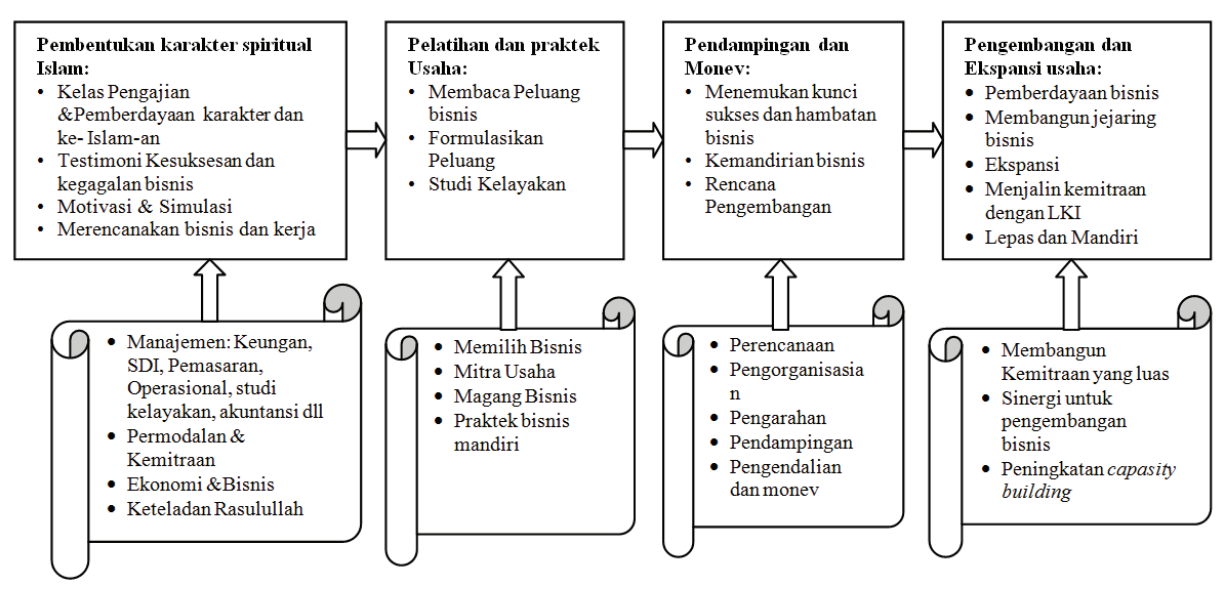

\section{Gambar 6}

\section{Proses Pemberdayaan Kesejahteraan Masyarakat Miskin}

Sumber: Formulasi Hasil Wawancara dari Key Informan

Proses ini merupakan proses Inkubator Bisnis. Inkubator bisnis ini merupakan suatu media atau tempat para pengusaha kecil dan menengah maupun calon wirausaha baru berlatih, bertanya dan berdiskusi untuk mengembangkan atau merealisasikan usahanya, maupun untuk memecahkan permasalahan manajemen usahanya, baik secara individu maupun kelompok. Proses tersebut dengan pemdampingan dari para ahli yang teruji dan berpengalaman dalam bidangnya. Pembangunan inkubator bisnis sebagai wadah pembentukan dan pembinaan pelaku wirausaha dan atau melahirkan 
wirausaha baru. Proses tersebut harus dibedakan berdasarkan kelompok usaha yang dibina, baik berdasarkan jenis maupun skala usaha serta potensi masyarakat yang telah ada selama ini. Pada sisi lain materi yang diberikan harus sederhana agar mudah dipahami khusus bagi mereka yang level pendidikannya rendah bahkan bagi mereka yang tidak pernah duduk pada pendidikan formal dan materinya berbasis pada ajaran Islam.

\section{Fomulasi Implementasi Waqaf}

Implementasi pemberian pemberdayaan yang diwujudkan dalam pemberian pembiayaan dari BMT yang didirikan dari modal waqaf uang adalah masyarakat yang telah mengikuti pembinaan mental spiritual keimanan selama waktu tertentu. Pembianaan spiritual keimanan tersebut dengan jangka waktu bervariasi tergantung kondisi keimanan masing-masing peserta program. Pembinaan paling awal adalah bagaimana menjalankan sholat lima waktunya dan apabila sholatnya sudah baik maka pembinaan selanjutnya adalah motivasi dan hakekat hidup manusia, keamanahan, kejujuran, ketrampilan, etos kerja dan manajemen kerja serta usaha yang sederhana, dengan jangka waktu mulai satu bulan sampai dengan setahun. Selama mengikuti masa pembinaan spiritual, mereka diberi dana untuk menemuhi kebutuhannya atau murni menerima dana konsumtif dari zakat, infaq dan shadaqah dari lembaga zakat. Apabila hasil evaluasi selama masa pembinaan spiritual di nilai telah layak diberi pembiayaan untuk usahanya telah ada selama ini dan pembiayaan bagi mereka yang masih start up usaha. Kriteria utama dalam penilaian kelayakan dalam menerima pembiayaan adalah rutinitas mengikuti pengajian dan kekhusukan sholat lima waktunya.

Pembiayaan yang diberikan menggunakan akad qard sehingga penerima pembiayaan akan mengembalikan sebesar pokoknya saja. Selama menerima pembiayaan diharuskan mengikuti pengajian rutin yang dilaksanakan sebulan sekali. Berdasarkan periode pengajian maka periode ini digunakan juga sebagai skema pengembalian pokok pinjaman selama jangka waktu periode pinjaman, atau menghadiri pengajian sekaligus membayar angsuran 
pembiayaannya. Jangka waktu pembiayaan antara setahun sampai tiga tahun dan besarnya angsuran diserahkan sesuai kemampuan dan kerelaan penerima pembiayaan, yang penting pembiayaan lunas selama jangka waktunya. Apabila ternyata terpaksa karena kondisi tidak mampu membayar angsuran sesuai periode bulannya maka diberikan tangguh sesuai kesanggupannya. Tetapi apabila betulbetul tidak mampu membayar angsuran dan total pokoknya maka dibebaskan sebagai gharimin tetapi tetap diwajibkan mengikuti pembinaan atau pengajian rutin. Mereka yang kondisi demikian suatu saat akan diberikan pembiayaan lagi apabila kondisi telah memungkinkan lagi.

Para penerima pembiayaan selalu mendapatkan pendampingan dalam menjalankan usaha atau dalam menekuni pekerjaannya. Model pendampingan ini secara otomatis memiliki fungsi kontrol terhadap usaha nasabah maka jika ada masalah pendamping segera menegtahui dan membantu memberikan solusi. Pendampingan tersebut berdampak pada pembiayaan yang bermasalah (non performing financing, NPF) sangat kecil bahkan bisa dikategorikan tidak ada. Hal ini juga didukung para penerima pembiayaan sangat amanah, jujur, pekerja keras dan profesioanal. Pengakuan informan pada saat ditanya mengapa amanah, jujur, kerja keras dan profesioanal mereka memberikan penjelasan karena sebelum menerima pembiayaan diberikan pembinaan pembentukan karakter tersebut dan ditekankan pada kekhusukan sholatnya. Dan mereka mengatakan dengan sholat yang khusuk membuat dirinya jadi disiplin dan selalu ingat larangan Allah tentang tidak boleh melakukan kecurangan atau kemungkaran. Saat ditanya lebih lanjut mengapa demikian? Mereka menjawab manfaat sholat yang khusuk akan mampu mencegah perbuatan keji dan mungkar. Dalam ini sholat membentuk dirinya berkarakter; amanah, jujur, pekerja keras dan profesioanal dalam mengelola dan mengembalikan pembiayaan sesuai dengan kesepakatan yang telah dibuat dengan BMT.

Pada sisi lain penerima pembiayan percaya bahwa apabila amanah dalam pengelolaan pembiayaan tersebut maka hidupnya akan berkah dan sejahtera duniawiyah dan ukhrowiyah. Dalam dirinya juga tertanam bahwa dana yang diterima adalah bersumber dari dana waqaf sehingga harus mengelolanya dengan amanah 
dan kemudian harus segera mengembalikan dana tersebut. Mereka berpikir bahwa dananya tersebut harus segera disalurkan kepada pihak lain yang juga membutuhkan dananya dan menurutnya ini merupakan cara dirinya menolong saudaranya yang juga membutuhkan pemberdayaan ekonomi. Faktanya mereka yang amanah demikian kondisi kehidupannya menjadi lebih baik atau dengan kata lain lebih sejahtera dibandingkan sebelum menerima pemberdayaan dari lembaga pengelola dana waqaf.

Para informan mengakui bahwa pendapatannya meningkat setelah menerima pemberdayaan dari lemabaga pengelola waqaf dan zakat. Dan bahkan ada yang mampu bertransformasi dari mustahiq menjadi muzakki. Mereka yang berhasil bertransformasi demikian diminta jadi mitra lembaga zakat dan waqaf untuk menjadi mentor bagi penerima pembiayaan dan pemberdayaan.

Kunci suksesnya implementasi waqaf dalam pemberdayaan untuk peningkatan kesejahteraan masyarakat miskin adalah; pertama, keberhasilan pembentukan karakter yang dimulai dengan pembinaan sholat lima waktu. Kedua, keberhasilan pemberdayaan masyarakat miskin ditentukan dalam pembianaan mental spiritual yang berupa jiwa amanah, jujur, pekerja keras dan profesioanal. Ketiga, pendampingan dan monetoring selama penerimaan pembiayaan adalah faktor kesuksesan yang dibutuhkan oleh penerima pembiayan agar berdaya secara sosial ekonominya apabila proses ini gagal maka sangat kecil kemungkinan masayarakat miskin akan sukses diberdayakan untuk keluar dari kemiskinannya.

Waqaf Uang yang dikelola dengan produktif dan ekonomis akan memiliki dampak lebih pada peningkatan kesejahteraan masyarakat miskin dibandingkan dengan waqaf aset tak bergerak. Mu'alim, (2014: 741) memberikan beberapa catatan, pertama, waqaf uang dapat digunakan untuk mengolah aset-aset waqaf berupa tanah-tanah kosong, untuk dikelola secara produktif melalui berbagai kegiatan ekonomi, atau dengan pembangunan gedung. Kedua, waqaf uang dapat dijadikan alternatif pembiayaan bagi lembaga-lembaga pendidikan Islam seperti pesantren, madrasah dan lainnya. Lembaga pendidikan Islam dapat lebih mandiri dan tidak lagi bergantung pada pendanaan pemerintah atau lainnya. 
Di samping itu, kemandirian sumber pendaaan akan memudahkan lembaga pendidikan dalam mengembangkan perannya dalam penguatan keilmuan Islam. Ketiga, waqaf uang sangat potensial untuk membantu para pelakuusaha kecil. Pada sisi lain ada tiga filosofi dasar yang harus diperhatikan dalam memberdayakan waqaf produktif. Pertama, pola manajemennya harus dalam bingkai proyek yang terintegrasi dimana dana waqaf akan dialokasikan untuk program-program pemberdayaan dengan segala macam biaya yang terangkum didalamnya. Kedua, asas kesejahteraan nazhir, menjadikan nazhirsebagai profesi yang memberikan harapan kepada lulusan terbaik umat dan profesi yang memberikan kesejahteraan dunia akherat. Ketiga, asas transparansi dan accountability. Badan waqaf harus melaporkan proses pengelolaan dananya kepada umat dalam bentuk auditedfinancial report, (Munir, 2013: 170).

\section{Kesimpulan}

Kunci sukses implementasi waqaf dalam pemberdayaan untuk peningkatan kesejahteraan masyarakat miskin adalah; 1) keberhasilan pembentukan karakter yang dimulai dengan pembiaan sholatnya khusussnya sholat lima waktu. 2) keberhasilan pemberdayaan masyarakat miskin ditentukan dalam pembianaan mental spiritual yang berupa jiwa amanah, jujur, kerja keras dan profesioanal. 3) Pendampingan dan monetoring selama penerimaan pembiayaan adalah faktor kesuksesan yang dibutuhkan oleh penerima pembiayan agar berdaya secara sosial ekonominya apabila proses ini gagal maka sangat kecil kemungkinan masayarakat miskin akan sukses diberdayakan untuk keluar dari kemiskinannya. Waqaf Uang yang dikelola dengan produktif dan ekonomis akan memiliki dampak lebih pada peningkatan kesejahteraan masyarakat miskin dibandingkan dengan waqaf aset tak bergerak. Pengelola waqaf (nazhir) harus menggunakan manajemen yang profesional dalam pengelolaan waqaf agar potensi waqaf yang telah ada dapat dikembangkan dan lebih diproduktifkan demi mewujudkan kesejahteraan umat atau masyarakat secara keseluruhan. 


\section{Daftar Pustaka}

Al-Bukhari, Muhammad ibn. 1981. Shahih al-Bukhari. Beirut: Dar al-Fikr.

Al-Husaini, Imam Taqiyuddin Abu Bakar bin Muhammad. 2007. Kifayat al-Akhyar.terj. Syarifuddin Anwar. Surabaya: Bijna Iman.

Al-Kabisi, Muhammad Abid Abdullah. 2004. Hukum Waqaf. Jakarta: Dhuafa Republika dan IIMaN.

Al-Khathib, Muhammad Al-Iqna'. t.t. t.j. Bairut: Darul Ma'rifah.

Al-Minawi. 1990. At-Tauqif alâ Muhimmât Ta'arif. Cairo: Alamul Kutub.

Basyir, Ahmad Azhar.1987. Hukum Islam Tentang Waqaf, Ijarah dan Syirkah.Bandung: PT. Al-Ma'arif.

Dahlan, Abdul Azis. 2003. Ensiklopedi Hukum Islam. Jakarta: PT. Ichtiar Baru Van Hoeve.

Darwanto.2012. Waqaf Sebagai Alternatif PendanaanPenguatan Ekonomi Masyarakat Indonesia. Jurnal Ilmu Manajemen Dan Akuntansi Terapan, Vol 3 No. 1.

Departemen Agama. 2007. Paradigma Baru Waqaf di Indonesia. Jakarta: Direktorat Pemberdayaan Waqaf Direktorat Jendral Bimbingan Masyarakat Islam Departemen Agama RI.

Djunaidi, Ahmad. et. al. 2007. Fikih Waqaf. Jakarta: Direktorat Pemberdayaan Waqaf Departemen Agama RI.

----. 2008. Menuju Era Waqaf Produktif. Cet. V. Jakarta: Mumtaz Publising.

Fauzia, Amelia. dan Ary Hermawan. dalam Thaha, Idris (Ed). 2003. Berderma untuk semua; Wacana dan Praktik Filantropi Islam. cet. 1. Jakarta: Teraju.

Hasan, Tholhah. 2009. Telaah Perkembangan Kebijakan Waqaf di Indonesia, Rabu, 22 April dalam http://www.antaranews. com, diakses 22 Desember 2015.

Hidayati, Tri Wahyu. 2010. Problematika Pengelolaan Waqaf di In- 
donesia. Jurnal Ekonomi dan Perbankan Muqtasid. STAIN Salatiga.

http://nasional.inilah.com/read/detail/2026676/jumlah-ukm-di-indonesia-capai-552-juta,diakses 16 Desember 2015.

Huda, Nurul. 2009. Manajemen Pengelolaan Tanah Waqaf di Majelis Waqaf dan Zakat, Infaq, Shadaqah (ZIS) Pimpinan Daerah Muhammadiyah Kabupaten Malang. Malang: Skripsi FEUIN.

Isfandiar, Ali Amin. 2008. Tinjauan Fiqh Muamalat dan Hukum Nasional tentang Waqaf di Indonesia. La_Riba Jurnal Ekonomi Islam, Vol II, No. 1.

Kementerian Agama Republik Indonesia.2013. Panduan Pemberdayaan Tanah Waqaf Produktif Strategis. Direktorat Jenderal Bimbingan Masyarakat Islam Direktorat Pemberdayaan Waqaf.

Mannan, M. A. 2005. Sertifikat Waqaf Tunai. Jakarta: CiBER bekerjasama dengan PKTTI-UI.

Miles, Matthew B \& A Michel Huberman. Qualitative Data Analysis. Jakarta: Universitas Indonesia Press.

Mu'alim, Mohammad dan Abdurrahman. 2014. Menggiatkan Waqaf Uang (Tunai) sebagai Upaya Peningkatan Kesejahteraan Masyarakat. Jurnal Bimas Islam, Vol. 7. No. IV.

Munir, Zainal Arifin. 2013. Revitalisasi Manajemen Waqaf Sebagai Penggerak Ekonomi Masyarakat. De Jure, Jurnal Syariah Dan Hukum, Vol. 5 No. 2.

Musgrave, R. A., and Musgrave, P. B. 1973.Public Finance in Theory and Practice. McGraw Hill.

Nafis, M. Cholil. 2009. Waqaf Uang Untuk Jaminan Sosial. Jurnal AlAwqaf, Vol. II, No. 2.

Najib, Tuti A. dan Ridwan al-Makassari. 2006. Waqaf Tuhan dan Agenda Kemanusiaan. Jakarta: CRSC.

Nasution, Mustafa E. et. al.2006.Pengenalan Eksklusif Ekonomi Islam.Jakarta: Kencana Prenada Media Group.

-----. 2006. Waqaf Tunai dan Sektor Volunteer, dalam Mustafa Edwin 
Nasution dan Uswatun Hasanah (ed). Waqaf Tunai Inovasi Finansial Islam. Jakarta: PSTTI UI.

Nawawi. t.t. Syarah Shahih Muslim.Juz.VI. Kairo: Sya’b.

Praja, Juhaya S. 1997.Perwaqafan Di Indonesia. Bandung: Yayasan Piara.

Prihatini, F. et. al. 2005.Hukum Islam Zakat dan Waqaf. Jakarta: Kerjasama Penerbit Papas Sinar Mentari dengan Badan Penerbit Fakultas Hukum Universitas Indonesia.

Qahaf, Mundzir. 2005.Manajemen Waqaf Produktif. Jakarta: Penerbit Khalifa.

-----. 1995.Sanadât Al-Ijârah, Al-Ma’had Al-Islâmy li Al-Buhûts wa AtTadrîb.Cairo: Dar as-Salam.

Ryandono, Muhamad Nafik Hadi. 2012. Tanggungjawab Lembaga Ekonomi Islam Dalam Mentransformasi Mustahiq Menjadi Muzakki. eL-Qist Journal Vol. 02, No. 02. Oktober 2012.

Salim, Agus. 2006. Teori dan Paradigma Penelitian Sosial. Yogyakarta: Tiara Wacana.

Suhadi, Imam. 2002.Waqaf untuk Kesejahteraan Umat. Yogyakarta: PT. Dana Bhakti Prima Yasa.

Undang-Undang Republik Indonesia Nomor 41 Tahun 2004 Tentang Waqaf.

Usman, Rachmadi. 2009.Hukum Perwaqafan di Indonesia.Jakarta: Sinar Grafika.

Yin, Robert K. 2002. Studi Kasus (Desain dan Metode). Jakarta: Rajagrafindo Persada.

Zahrah, Muhammad Abu. 1995.Muhadharât fi Al-Waqf. Cairo: Darussalam.

Zuhaili, Wahbah.t.t. Al-fiqhu al-islami waadillatuhu. Damaskus: Dar al-fikr al-mu'ashir. 